\title{
Association of Single Nucleotide Polymorphisms in the CYP19A1 Gene with Female Pattern Hair Loss in a Chinese Population
}

\author{
Wenlong Rui Youyu Sheng Ruiming Hu Ying Miao Yumei Han \\ Xia Guo Sisi Qi Feng Xu Jinhua Xu Qinping Yang \\ Department of Dermatology, Huashan Hospital, Shanghai Medical College, Fudan University, Shanghai, China
}

\section{Key Words}

Female pattern hair loss $\cdot$ CYP19A1 gene $\cdot$ Single nucleotide polymorphisms

\begin{abstract}
Background: It has been suggested that the single nucleotide polymorphism (SNP) of the CYP19A1 gene encoding aromatase may affect the development of female pattern hair loss (FPHL). Objective: Our aim was to investigate the association of CYP19A1 gene SNPs with FPHL in a Chinese population. Methods: Two hundred Chinese Han patients with FPHL and 200 controls were enrolled into our study. SNaPshot technology was used to detect CYP19A1 gene candidate SNPs. Results: The allele frequencies and distributions of rs6493497 and rs7176005 were significantly different between FPHL and control subjects $(p<0.001$ and $p<$ 0.001 vs. $p<0.001$ and $p=0.003$ ). Conclusion: The rs6493497 and rs7176005 SNPs of the CYP19A1 gene may be genetic markers that influence the risk of FPHL in this Chinese population.

(c) 2015 The Author(s)

Published by S. Karger AG, Basel
\end{abstract}

Wenlong Rui and Youyu Sheng contributed equally to this work.

\section{Introduction}

Female pattern hair loss (FPHL) is the most common hair loss disorder in women, characterized by diffuse central thinning over the mid-frontal scalp and progressive frontal accentuation [1]. The prevalence of FPHL increases with advancing age, from approximately $12 \%$ among women aged $20-29$ years to more than $50 \%$ in women older than 80 [2]. Although the prevalence of this condition seems to be lower in the Chinese population, the number of women with FPHL is enormous due to the large population of China $[3,4]$.

The hallmark feature of FPHL is the progressive transformation of terminal hair follicles to vellus hair follicles, a process called follicular miniaturization that is histologically indistinguishable from male androgenetic alopecia (MAGA) in part due to a genetic predisposition influenced by androgens [5-7]. However, although the androgen-dependent nature of MAGA is well established, this has not been similarly proven for FPHL. FPHL can occur alone and sometimes may be seen together with hyperandrogenemia and other signs of hyperandrogenism (hirsutism, acne), but most women with FPHL have androgen levels within the normal range [1]. Moreover, women without circulating androgens may also develop FPHL, suggesting a possible role for non-androgen-dependent mechanisms [8].

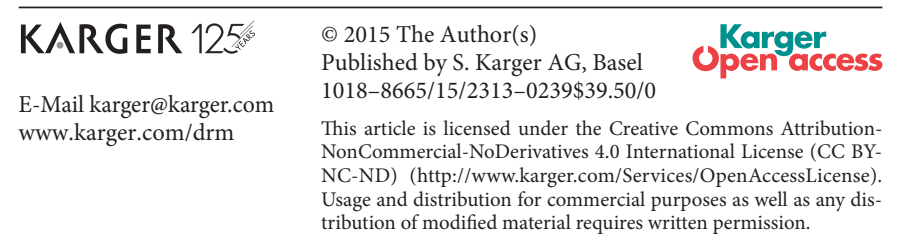

Qinping Yang, MD

Department of Dermatology, Huashan Hospital

Shanghai Medical College, Fudan University

12 Middle Wulumuqi Road, Shanghai 200040 (China)

E-Mail qpyang_shhs1@126.com tribution of modified material requires written permission. 
Table 1. Details of the 12 selected SNPs

\begin{tabular}{lllll}
\hline SNP & Position & Allele & $\begin{array}{l}\text { Minor allele frequency } \\
\text { (HAPMAP-HCB) }\end{array}$ & Specific disorder \\
\hline rs10046 & 3'-UTR_exon11 $^{\prime}$ & A/G & 0.474 & associated with breast cancer [16, 17] \\
rs2255192 & 3'-UTR_exon11 & C/T & 0.175 & tag SNP \\
rs2414096 & intron 4 & A/G & 0.477 & associated with PCOS [14] \\
rs28892002 & $5^{\prime}$-flanking & A/G & 0.244 & Asian endemic \\
rs4646 & 3'-UTR_exon11 & A/C & 0.296 & associated with FPHL [15] \\
rs4775936 & intron 3 & $\mathrm{C} / \mathrm{T}$ & 0.423 & associated with bone mineral density in women; tag SNP [18] \\
rs6493497 & $5^{\prime}$-flanking & $\mathrm{A} / \mathrm{G}$ & 0.237 & associated with breast cancer; tag SNP; promoters [19] \\
rs700519 & intron 6 & $\mathrm{A} / \mathrm{G}$ & 0.132 & associated with PCOS [20] \\
rs7176005 & $5^{\prime}$-flanking & $\mathrm{C} / \mathrm{T}$ & 0.216 & associated with breast cancer; tag SNP; promoters [19] \\
rs727479 & intron 4 & $\mathrm{A} / \mathrm{C}$ & 0.265 & associated with breast cancer [21] \\
rs749292 & intron 3 & $\mathrm{A} / \mathrm{G}$ & 0.496 & associated with ovarian cancer [22] \\
rs752760 & 5'-flanking & $\mathrm{C} / \mathrm{T}$ & 0.383 & associated with sex hormones; tag SNP [23] \\
\hline
\end{tabular}

The role of estrogens in scalp hair growth in both sexes is less clear and has not been as extensively studied as that of androgens. Aromatase is the key enzyme required to convert C19 precursor androgens to aromatic C18 estrogens in the hair follicle, and women may have less severe hair loss than men due to lower levels of $5 a$-reductase and higher levels of aromatase in susceptible hair follicles [912]. Aromatase is encoded by CYP19A1, which is located on chromosome 15q21.1. The CYP19A1 gene plays a critical role in regulating androgen metabolism; thus, CYP19A1 research has become a hot topic in the diagnosis of breast cancer, polycystic ovary syndrome, and acne, all of which are sex hormone-associated clinical challenges $[13,14]$. An Australian genome-wide association study on the CYP19A1 gene demonstrated that CYP19A1 single nucleotide polymorphisms (SNPs) may be associated with FPHL, and the authors stressed the need for replicative studies to confirm their findings [15]. We thereupon conducted this study to explore the association of CYP19A1 gene SNPs with FPHL in a Chinese Han population.

\section{Materials and Methods}

\section{Subjects}

We selected 12 SNPs in the CYP19A1 gene. The candidate SNPs have been shown to be associated with FPHL, breast cancer, polycystic ovary, syndrome and acne in former studies. Detailed information on the 12 SNPs is shown in table 1.

The selected SNPs were genotyped in 200 unrelated women with FPHL from the hair loss clinic. The inclusion criterion was a grade of II to III on the Ludwig scale. All patients were diagnosed by at least 2 independent experienced dermatologists. As controls, 200 healthy female subjects from the medical examination center of our hospital were also genotyped. Each individual in the control group was specifically screened for absence of FPHL by experienced dermatologists and had no hair shedding or decrease in hair density and no previous history of or treatment for hair loss. All tested women ranged from 16 to 48 years of age and belonged to the Chinese Han ethnic group.

For the association analysis, the following SNP quality criteria were used as exclusion criteria: minor allele frequency $<1 \%$ and $\mathrm{p}<0.05$ for Hardy-Weinberg equilibrium in controls. After applying these criteria, 12 SNPs remained eligible for analysis in our study.

The present work was approved by the Ethics Committee of Huashan Hospital, Fudan University. All participants gave written informed consent for the genetic studies.

\section{Extraction of Genomic DNA}

Genomic DNA was isolated from fresh peripheral blood using a QIAamp DNA Blood Kit (Qiagen, Valencia, Calif., USA) according to the manufacturer's instructions.

\section{Polymerase Chain Reaction and Sequencing}

In our study, $\mathrm{SNaPshot} \mathrm{SNP}$ classification technology was used on 12 SNP loci in the 400 samples. We designed 12 pairs of polymerase chain reaction (PCR) primers to amplify 12 loci (110- to 495-bp fragments). We also designed 12 primers to localize adjacently to the extension of SNP loci and used them for single-base extension. Primers were designed using Primer3 software (http:// bioinfo.ut.ee/primer3-0.4.0/). PCR products were obtained by HotStarTaq multiple PCR (Qiagen). Genotyping was performed in multiplex reactions using an ABI 3730xl sequencer. SNP classification analysis was performed using GeneMapper version 4.1 (Applied Biosystems Co., Ltd., USA).

\section{Statistical Analysis}

The applied statistical analysis involved Hardy-Weinberg equilibrium tests for all 12 SNPs. Genotype and allele frequency distributions were compared using $\chi^{2}$ tests and linkage disequilibrium analyses with UNPHASED 3.1.4. $\mathrm{p}<0.05$ was considered statistically significant. 
Table 2. Allele frequencies in SNPs of the CYP19A1 gene

\begin{tabular}{|c|c|c|c|c|}
\hline SNP & Allele & Patients & Controls & $\chi^{2} / \mathrm{p}$ \\
\hline \multirow[t]{2}{*}{ rs10046 } & $\mathrm{A}$ & 216 & 218 & \multirow[t]{2}{*}{$0.020 / 0.887$} \\
\hline & G & 184 & 182 & \\
\hline \multirow[t]{2}{*}{ rs2255192 } & $\mathrm{C}$ & 327 & 335 & \multirow[t]{2}{*}{$0.560 / 0.454$} \\
\hline & $\mathrm{T}$ & 73 & 65 & \\
\hline \multirow[t]{2}{*}{ rs2414096 } & A & 177 & 185 & \multirow[t]{2}{*}{$0.323 / 0.570$} \\
\hline & G & 223 & 215 & \\
\hline \multirow[t]{2}{*}{ rs28892002 } & $\mathrm{A}$ & 116 & 113 & \multirow[t]{2}{*}{$0.055 / 0.814$} \\
\hline & G & 284 & 287 & \\
\hline \multirow[t]{2}{*}{ rs4646 } & $\mathrm{A}$ & 111 & 116 & \multirow[t]{2}{*}{$0.154 / 0.695$} \\
\hline & $\mathrm{C}$ & 289 & 284 & \\
\hline \multirow[t]{2}{*}{ rs4775936 } & $\mathrm{C}$ & 227 & 223 & \multirow[t]{2}{*}{$0.081 / 0.776$} \\
\hline & $\mathrm{T}$ & 173 & 177 & \\
\hline \multirow[t]{2}{*}{ rs6493497 } & $\mathrm{A}$ & 62 & 100 & \multirow[t]{2}{*}{$11.177 /<0.00$} \\
\hline & G & 338 & 300 & \\
\hline \multirow[t]{2}{*}{ rs700519 } & $\mathrm{A}$ & 64 & 56 & \multirow[t]{2}{*}{$0.627 / 0.428$} \\
\hline & G & 336 & 344 & \\
\hline \multirow[t]{2}{*}{ rs7176005 } & $\mathrm{C}$ & 338 & 300 & \multirow[t]{2}{*}{$11.177 /<0.00$} \\
\hline & $\mathrm{T}$ & 62 & 100 & \\
\hline \multirow[t]{2}{*}{ rs727479 } & $\mathrm{A}$ & 293 & 279 & \multirow[t]{2}{*}{$1.202 / 0.273$} \\
\hline & $\mathrm{C}$ & 107 & 121 & \\
\hline \multirow[t]{2}{*}{ rs749292 } & $\mathrm{A}$ & 193 & 173 & \multirow[t]{2}{*}{$2.015 / 0.156$} \\
\hline & G & 207 & 227 & \\
\hline \multirow[t]{2}{*}{ rs752760 } & $\mathrm{C}$ & 169 & 146 & \multirow[t]{2}{*}{$2.770 / 0.096$} \\
\hline & $\mathrm{T}$ & 231 & 254 & \\
\hline
\end{tabular}

\section{Results}

The median age of the 200 FPHL patients was 31 years (mean $31.38 \pm 4.09$ ) and that of the 200 control patients was 33 years (mean $33.51 \pm 5.02$ ). Of the 200 FPHL patients, 142 exhibited moderate FPHL (Ludwig grade II) and 58 exhibited severe FPHL (Ludwig grade III). In the rs6493497 patient group, the arginine (A) and guanine (G) frequencies $(A=62$ and $G=338)$ were significantly different from those of the control group $(A=100$ and $\mathrm{G}=300, \mathrm{p}<0.001)$. Similarly, in the rs7176005 patient group, the thymine $(\mathrm{T})$ and cytosine $(\mathrm{C})$ frequencies $(\mathrm{T}=$ 62 and $\mathrm{C}=338$ ) were significantly different from those of the control group ( $\mathrm{T}=100$ and $\mathrm{C}=300, \mathrm{p}<0.001$ ), as shown in table 2. Furthermore, in the rs6493497 patient group, the $A$ and $G$ genotype distributions $(\mathrm{AA}=6$, $A G=50$, and $G G=144$ ) were significantly different from those of the control group $(\mathrm{AA}=12, \mathrm{AG}=76$, and $\mathrm{GG}=$
Table 3. Distribution of SNP genotypes of the CYP19A1 gene

\begin{tabular}{|c|c|c|c|c|}
\hline SNP & Genes & Patients & Controls & $\chi^{2} / \mathrm{p}$ \\
\hline \multirow[t]{3}{*}{ rs10046 } & $\mathrm{AA}$ & 63 & 55 & \multirow[t]{3}{*}{$3.369 / 0.186$} \\
\hline & AG & 90 & 108 & \\
\hline & GG & 47 & 37 & \\
\hline \multirow[t]{3}{*}{ rs2255192 } & $\mathrm{CC}$ & 133 & 139 & \multirow[t]{3}{*}{$0.668 / 0.716$} \\
\hline & CT & 61 & 57 & \\
\hline & $\mathrm{TT}$ & 6 & 4 & \\
\hline \multirow[t]{3}{*}{ rs2414096 } & AA & 39 & 39 & \multirow[t]{3}{*}{$0.862 / 0.650$} \\
\hline & $\mathrm{AG}$ & 99 & 107 & \\
\hline & GG & 62 & 54 & \\
\hline \multirow[t]{3}{*}{ rs28892002 } & AA & 19 & 21 & \multirow[t]{3}{*}{$0.547 / 0.761$} \\
\hline & AG & 78 & 71 & \\
\hline & GG & 103 & 108 & \\
\hline \multirow[t]{3}{*}{ rs4646 } & $\mathrm{AA}$ & 16 & 16 & \multirow[t]{3}{*}{$0.275 / 0.871$} \\
\hline & $\mathrm{AC}$ & 79 & 84 & \\
\hline & $\mathrm{CC}$ & 105 & 100 & \\
\hline \multirow[t]{3}{*}{ rs4775936 } & $\mathrm{CC}$ & 65 & 57 & \multirow[t]{3}{*}{$1.446 / 0.485$} \\
\hline & $\mathrm{CT}$ & 97 & 109 & \\
\hline & $\mathrm{TT}$ & 38 & 34 & \\
\hline \multirow[t]{3}{*}{ rs6493497 } & GG & 144 & 112 & \multirow[t]{3}{*}{$11.365 / 0.003$} \\
\hline & $\mathrm{AG}$ & 50 & 76 & \\
\hline & AA & 12 & 6 & \\
\hline \multirow[t]{3}{*}{ rs700519 } & $\mathrm{AA}$ & 4 & 2 & \multirow[t]{3}{*}{$0.941 / 0.625$} \\
\hline & $\mathrm{AG}$ & 56 & 52 & \\
\hline & GG & 140 & 146 & \\
\hline \multirow[t]{3}{*}{ rs7176005 } & $\mathrm{CC}$ & 144 & 112 & \multirow[t]{3}{*}{$11.365 / 0.003$} \\
\hline & CT & 50 & 76 & \\
\hline & $\mathrm{TT}$ & 6 & 12 & \\
\hline \multirow[t]{3}{*}{ rs727479 } & $\mathrm{AA}$ & 104 & 94 & \multirow[t]{3}{*}{$1.325 / 0.516$} \\
\hline & $\mathrm{AC}$ & 85 & 91 & \\
\hline & $\mathrm{CC}$ & 11 & 15 & \\
\hline \multirow[t]{3}{*}{ rs749292 } & $\mathrm{AA}$ & 45 & 33 & \multirow[t]{3}{*}{$2.494 / 0.287$} \\
\hline & AG & 103 & 107 & \\
\hline & GG & 52 & 60 & \\
\hline \multirow[t]{3}{*}{ rs752760 } & $\mathrm{CC}$ & 36 & 26 & \multirow[t]{3}{*}{$2.810 / 0.245$} \\
\hline & $\mathrm{CT}$ & 97 & 94 & \\
\hline & $\mathrm{TT}$ & 67 & 80 & \\
\hline
\end{tabular}

$112, \mathrm{p}=0.003)$. The same was true for the rs7176005 $\mathrm{T}$ and $\mathrm{C}$ distributions (TT $=6, \mathrm{CT}=50$, and $\mathrm{CC}=144$ ) relative to the control group ( $\mathrm{TT}=12, \mathrm{CT}=76$, and $\mathrm{CC}=$ $112, \mathrm{p}=0.003)$, as shown in table 3 .

For the rs6493497 Ludwig II group, the allele frequencies of $A$ and $G(A=53$ and $G=231)$ were significantly different from those of the Ludwig III group $(A=9$ and $\mathrm{G}=107, \mathrm{p}=0.006$ ). Similarly, in the rs7176005 Ludwig II 
Table 4. Allele frequencies of rs6493497 and rs7176005 in moderate and severe FPHL patients

\begin{tabular}{llrrl}
\hline SNP & Allele & Moderate & Severe & $\chi^{2} / \mathrm{p}$ \\
\hline rs6493497 & $\mathrm{A}$ & 53 & 9 & $7.476 / 0.006$ \\
& $\mathrm{G}$ & 231 & 107 & \\
\hline rs7176005 & $\mathrm{T}$ & 53 & 9 & $7.476 / 0.006$ \\
& $\mathrm{C}$ & 231 & 107 & \\
\hline
\end{tabular}

group, the $\mathrm{T}$ and $\mathrm{C}$ frequencies $(\mathrm{T}=53$ and $\mathrm{C}=231$ ) were significantly different from those of the Ludwig III group ( $\mathrm{T}=9$ and $\mathrm{C}=107, \mathrm{p}=0.006$ ), as shown in table 4 . For the rs6493497 Ludwig II group, the A and G genotype distributions ( $\mathrm{AA}=6, \mathrm{AG}=41$, and $\mathrm{GG}=95$ ) were significantly different from those of the Ludwig III group $(\mathrm{AA}=0, \mathrm{AG}=9$, and $\mathrm{GG}=49, \mathrm{p}=0.028)$. Similarly, in the rs7176005 Ludwig II group, the T and C genotype distributions ( $\mathrm{TT}=6, \mathrm{CT}=41$, and $\mathrm{CC}=95$ ) were significantly different from those of the Ludwig III group ( $\mathrm{TT}=0, \mathrm{CT}=9$, and $\mathrm{CC}=49, \mathrm{p}=0.028)$, as shown in table 5. In the analysis of linkage disequilibrium, we found that rs6493497 and rs7176005 were in complete linkage disequilibrium $\left(\mathrm{r}^{2}=1\right)$.

\section{Discussion}

FPHL is also termed female androgenetic alopecia and is considered the female equivalent of MAGA due to its possible association with an altered androgen metabolism and familial occurrence. However, although the androgen-dependent nature of MAGA is well established, this has not been similarly proven for FPHL. While pattern hair loss and hirsutism are seen in women with hyperandrogenism, most women with FPHL have androgen levels within the normal range [24]. FPHL with hypopituitarism and undetectable androgens suggests the possibility that it also can be induced by factors independent of androgens [8]. Therefore, the term 'female pattern hair loss' is the preferred term over 'female androgenetic alopecia'.

There are fewer reported genetic association studies for FPHL compared to MAGA [25]. Recent studies have shown no involvement of the well-established locus on chromosome 20p11 in FPHL but have suggested that the androgen receptor/ectodysplasin A2 receptor (EDA2R)
Table 5. Genotype distribution of rs6493497 and rs7176005 in moderate and severe FPHL patients

\begin{tabular}{llccl}
\hline SNP & Genotype & Moderate & Severe & $\chi^{2} / \mathrm{p}$ \\
\hline rs6493497 & AA & 6 & 0 & $7.157 / 0.028$ \\
& AG & 41 & 9 & \\
& GG & 95 & 49 & \\
\hline rs7176005 & CC & 95 & 49 & $7.157 / 0.028$ \\
& CT & 41 & 9 & \\
& TT & 6 & 0 & \\
\hline
\end{tabular}

locus on the X chromosome confers susceptibility to early-onset FPHL [26]. In other studies, no association was found between steroid $5 a$-reductase isoform genes or sex steroid hormone receptors and FPHL [27]. Moreover, an Australian genome-wide association study suggested that the aromatase gene (CYP19A1) may contribute to FPHL, but this was not confirmed in another study $[15,28]$.

This study explores the relationship between FPHL and SNPs in the CYP19A1 gene in a Chinese Han population. Based on our results, the rs6493497 and rs7176005 alleles were differentially expressed between the FPHL patient group and the control group in a statistically significant manner. We used linkage disequilibrium analysis to demonstrate that these two SNPs are in complete linkage disequilibrium $\left(\mathrm{r}^{2}=1\right)$.

The SNPs rs6493497 and rs7176005 are located on the promoter sequence of the CYP19A1 gene, which is upstream of exon 1 . The expression of exon 1 is strongly associated with aromatase activity. Since the start of transcription is a critical stage for gene expression, the promoter structure affects the affinity between itself and the RNA polymerase, thereby directly influencing the expression level of the gene in question. Regarding these two particular SNPs, there were similar findings in a recently published study on breast cancer in which further functional studies were proposed to examine their impact on CYP19A1 gene transcription [29].

While the findings of Yip et al. [15] pointed out that the rs4646 allele positively correlates with FPHL in Caucasian patients, our study showed that there was no statistical significance for the expression of rs4646 between the FPHL patient group $(\mathrm{A}=111$ and $\mathrm{C}=289)$ and the control group $(A=116$ and $C=284, p=0.695)$. Additionally, consistent with the negative results of the study of Redler et al. [28] on the CYP19A1 gene of rs4646 in British and German FPHL patients, we demonstrated that there is no statistically significant difference $(\mathrm{p}=0.871)$ 
in the gene pattern between our tested FPHL patient group $(\mathrm{AA}=16, \mathrm{AC}=79$, and $\mathrm{CC}=105)$ and the control group $(\mathrm{AA}=16, \mathrm{AC}=84$, and $\mathrm{CC}=100)$. We attribute the possible discrepancy between our findings and those of Yip et al. [15] to ethnic differences.

The greatest limitation of this study is the small sample of a total of 200 patients and 200 controls for a case-control study, and a subgroup of 58 severely affected women is definitely too small to generate valid results. As calculated by QUANTO 1.2 (level of significance: 0.05), the power for the FPHL patients and the control group was 0.88 (power $\geq 0.8$ is a general threshold for acceptable). Because of the limited number of severe cases available, the power for the Ludwig II and III groups was relatively low (i.e. 0.76); however, the result was enough to suggest this trend. A larger sample set should be analyzed in a further study.
In conclusion, our study shows that the rs6493497 and rs7176005 alleles of the CYP19A1 gene locus are associated with FPHL. Furthermore, the rs649349 genotype GG and the rs7176005 genotype CC may increase the risk of FPHL in the Chinese Han ethnic group.

\section{Acknowledgement}

The present work (2014SY003) was sponsored by the Shanghai Municipal Bureau of Health.

\section{Disclosure Statement}

The authors disclose no conflicts of interest.

\section{References}

1 Olsen EA: Female pattern hair loss. J Am Acad Dermatol 2001;45:S70-S80.

2 Gan DC, Sinclair RD: Prevalence of male and female pattern hair loss in Maryborough. J Investig Dermatol Symp Proc 2005;10:184-189.

-3 Xu F, Sheng YY, Mu ZL, Lou W, Zhou J, Ren YT, Qi SS, Wang XS, Fu ZW, Yang QP: Prevalence and types of androgenetic alopecia in Shanghai, China: a community-based study. Br J Dermatol 2009;160:629-632.

-4 Wang TL, Zhou C, Shen YW, Wang XY, Ding XL, Tian S, Liu Y, Peng GH, Xue SQ, Zhou JE, Wang RL, Meng XM, Pei GD, Bai YH, Liu Q, Li H, Zhang JZ: Prevalence of androgenetic alopecia in China: a community-based study in six cities. Br J Dermatol 2010;162:843-847.

$\checkmark 5$ Messenger AG, Sinclair R: Follicular miniaturization in female pattern hair loss: clinicopathological correlations. Br J Dermatol 2006 155:926-930.

6 Whiting DA, Waldstreicher J, Sanchez M, Kaufman KD: Measuring reversal of hair miniaturization in androgenetic alopecia by follicular counts in horizontal sections of serial scalp biopsies: results of finasteride $1 \mathrm{mg}$ treatment of men and postmenopausal women. J Investig Dermatol Symp Proc 1999;4: 282-284.

7 Randall VA: Androgens and hair growth. Dermatol Ther 2008;21:314-328.

-8 Orme S, Cullen DR, Messenger AG: Diffuse female hair loss: are androgens necessary? $\mathrm{Br}$ J Dermatol 1999;141:521-523.

-9 Ohnemus U, Uenalan M, Inzunza J, Gustafsson JA, Paus R: The hair follicle as an estrogen target and source. Endocr Rev 2006;27:677706

Association of CYP19A1 SNPs with FPHL in a Chinese Population
0 Meinhardt U, Mullis PE: The aromatase cytochrome p-450 and its clinical impact. Horm Res 2002;57:145-152.

11 Bulun SE: Aromatase deficiency in women and men: would you have predicted the phenotypes? J Clin Endocrinol Metab 1998;81: 867-871.

12 Sawaya ME, Price VH: Different levels of 5alpha-reductase type I and II, aromatase, and androgen receptor in hair follicles of women and men with androgenetic alopecia. J Invest Dermatol 1997;109:296-300

13 Probst-Hensch NM, Ingles SA, Diep AT, Haile RW, Stanczyk FZ, Kolonel LN, Henderson BE: Aromatase and breast cancer susceptibility. Endocr Relat Cancer 1999;6:165-173.

$\checkmark 14$ Jin JL, Sun J, Ge HJ, Cao YX, Wu XK, Liang FJ, Sun HX, Ke L, Yi L, Wu ZW, Wang Y: Association between CYP19 gene SNP rs2414096 polymorphism and polycystic ovary syndrome in Chinese women. BMC Med Genet 2009;10:139.

15 Yip L, Zaloumis S, Irwin D, Severi G, Hopper J, Giles G, Harrap S, Sinclair R, Ellis J: Genewide association study between the aromatase gene (CYP19A1) and female pattern hair loss. Br J Dermatol 2009;161:289-294.

16 Zins K, Mogg M, Schneeberger C, Abraham D, Schreiber M: Analysis of the rs 10046 polymorphism of aromatase (CYP19) in premenopausal onset of human breast cancer. Int J Mol Sci 2014;15:712-724.

17 Pineda B, García-Pérez MÁ, Cano A, Lluch A, Eroles P: Associations between aromatase CYP19 rs10046 polymorphism and breast cancer risk: from a case-control to a metaanalysis of 20,098 subjects. PLoS One 2013; 8:e53902.
18 Enjuanes A, Garcia-Giralt N, Supervía A, Nogués X, Ruiz-Gaspà S, Bustamante $\mathrm{M}, \mathrm{Mel}$ libovsky L, Grinberg D, Balcells S, Díez-Pérez A: A new SNP in a negative regulatory region of the CYP19A1 gene is associated with lumbar spine BMD in postmenopausal women. Bone 2006;38:738-743.

19 Straume AH, Knappskog S, Lønning PE: Effect of CYP19 rs6493497 and rs7176005 haplotype status on in vivo aromatase transcription, plasma and tissue estrogen levels in postmenopausal women. J Steroid Biochem Mol Biol 2012;128:69-75.

20 Wang $\mathrm{H}, \mathrm{Li}$ Q, Wang T, Yang G, Wang Y, Zhang X, Sang Q, Wang H, Zhao X, Xing Q, Shi J, He L, Wang L: A common polymorphism in the human aromatase gene alters the risk for polycystic ovary syndrome and modifies aromatase activity in vitro. Mol Hum Reprod 2011;17:386-391.

21 Raskin L, Lejbkowicz F, Barnett-Griness O, Dishon S, Almog R, Rennert G: BRCA1 breast cancer risk is modified by CYP19 polymorphisms in Ashkenazi Jews. Cancer Epidemiol Biomarkers Prev 2009;18:1617-1623.

-22 Goodman MT, Lurie G, Thompson PJ, McDuffie KE, Carney ME: Association of two common single-nucleotide polymorphisms in the CYP19A1 locus and ovarian cancer risk. Endocr Relat Cancer 2008;15:10551060 .

23 Kidokoro K, Ino K, Hirose K, Kajiyama H, Hosono S, Suzuki T, Kawase T, Hiraki A, Hamajima N, Tanaka H, Tajima K, Kikkawa F, Matsuo K: Association between CYP19A1 polymorphisms and sex hormones in postmenopausal Japanese women. J Hum Genet 2009;54:78-85. 
24 Schmidt JB, Lindmaier A, Trenz A, Schurz B, Spona J: Hormone studies in females with androgenetic hair loss. Gynecol Obstet Invest 1991;31:235-239.

$\rightarrow 25$ Yip L, Rufaut N, Sinclair R: Role of genetics and sex steroid hormones in male androgenetic alopecia and female pattern hair loss: an update of what we now know. Australas J Dermatol 2011;52:81-88.

26 Redler S, Brockschmidt FF, Tazi-Ahnini R, Drichel D, Birch MP, Dobson K, Giehl KA, Herms S, Refke M, Kluck N, Kruse R, Lutz G, Wolff H, Böhm M, Becker T, Nöthen MM, Messenger AG, Betz RC: Investigation of the male pattern baldness major genetic suscepti- bility loci AR/EDA2R and 20p11 in female pattern hair loss. Br J Dermatol 2012;166: 1314-1318.

27 Redler S, Tazi-Ahnini R, Drichel D, Birch MP, Brockschmidt FF, Dobson K, Giehl KA, Refke M, Kluck N, Kruse R, Lutz G, Wolff H, Böhm M, Becker T, Nöthen MM, Betz RC, Messenger AG: Selected variants of the steroid5-alpha-reductase isoforms SRD5A1 and SRD5A2 and the sex steroid hormone receptors ESR1, ESR2 and PGR: no association with female pattern hair loss identified. Exp Dermatol 2012;21:390-393.

28 Redler S, Birch MP, Drichel D, Dobson K, Brockschmidt FF, Tazi-Ahnini R, Giehl KA,
Kluck N, Kruse R, Lutz G, Wolff H, Becker T, Nöthen MM, Messenger AG, Betz RC: Investigation of variants of the aromatase gene (CYP19A1) in female pattern hair loss. Br J Dermatol 2011;165:703-705.

29 Wang L, Ellsworth KA, Moon I, Pelleymounter LL, Eckloff BW, Martin YN, Fridley BL, Jenkins GD, Batzler A, Suman VJ, Ravi S, Dixon JM, Miller WR, Wieben ED, Buzdar A, Weinshilboum RM, Ingle JN: Functional genetic polymorphisms in the aromatase gene CYP19 vary the response of breast cancer patients to neoadjuvant therapy with aromatase inhibitors. Cancer Res 2010;70:319-328. 